\title{
ERRATUM
}

\section{Erratum to: Photosynthetic characteristics of marine aerobic anoxygenic phototrophic bacteria Roseobacter and Erythrobacter strains}

Yuki Sato-Takabe $\cdot$ Koji Hamasaki •

Koji Suzuki

Published online: 23 November 2011

(C) Springer-Verlag 2011

\section{Erratum to: Arch Microbiol}

DOI 10.1007/s00203-011-0761-2

In the original publication the $\mathrm{x}$-axis labelling in Fig. 2 was not described and the unit "ag ml $\mathrm{m}^{-1}$ " on y-axis of Fig. 2c should read "ag cell ${ }^{-1}$ ". The corrected figure is given here.

The online version of the original article can be found under doi:10.1007/s00203-011-0761-2.

Y. Sato-Takabe $(\square) \cdot$ K. Suzuki

Graduate School of Environmental Science,

Hokkaido University, North 10 West 5,

Kita-ku, Sapporo 060-0810, Japan

e-mail: satoyuki@ees.hokudai.ac.jp

Y. Sato-Takabe $\cdot$ K. Hamasaki

Ocean Research Institute,

The University of Tokyo, Tokyo, Japan

K. Suzuki

Faculty of Environmental Earth Science,

Hokkaido University, Sapporo, Japan
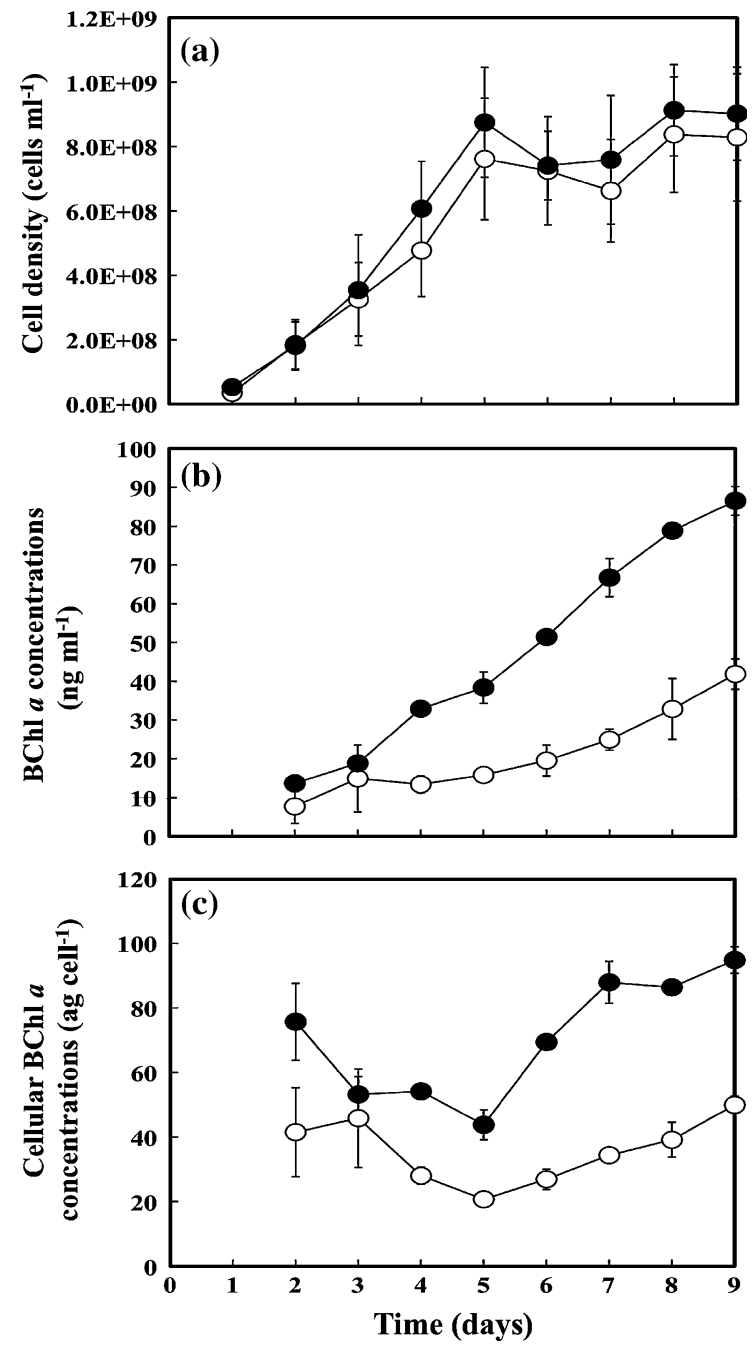

Fig. 2 Changes over time in the a cell densities, b BChl $a$ concentration, and c cellular BChl $a$ levels of OBYS 0001 (filled circle) and NBRC 14126 (open circle) 